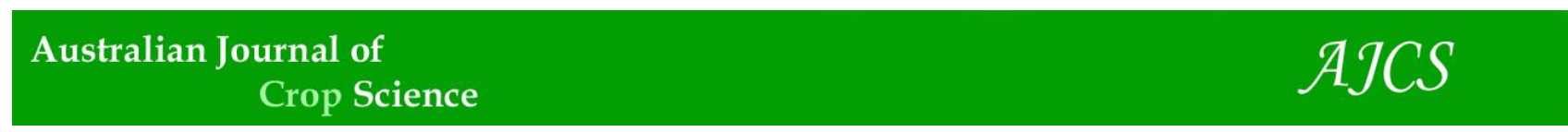

AJCS 11(05):596-604 (2017)

ISSN:1835-2707

doi: 10.21475/ajcs.17.11.05.p419

\title{
Removal of cadmium (Cd) from low quality water by bentonite applied in the soil
}

\author{
Gilvanise Alves Tito ${ }^{1}$, Lucia Helena Garófalo Chaves $^{1^{*}}$, Josely Dantas Fernandes ${ }^{2}$, Francisco de Assis \\ Santos e Silva ${ }^{1}$
}

${ }^{1}$ Universidade Federal de Campina Grande, Departamento de Engenharia Agrícola, Av. Aprigio Veloso, 882, CEP 58429-900, Campina Grande, Estado da Paraíba, Brasil

${ }^{2}$ Universidade Estadual da Paraíba, Sítio Imbaúba, sn, Zona Rural, CEP 58117-000, Lagoa Seca, Estado da

Paraíba, Brasil

*Corresponding author: lhgarofalo@hotmail.com

\begin{abstract}
The present study investigated the removal of cadmium from low quality water by bentonite applied in the soil using with the plants test radish, corn and sugar beet. The experiments were carried out in a greenhouse, with a completely randomized design with four replications. The experimental units were plastic pots with a capacity of $5 \mathrm{~kg}$ for beets and radish; and for corn in plastic pots with 14 $\mathrm{kg}$. The soil was mixed with increasing doses of bentonite equivalent to $0 ; 30 ; 60$ and $90 \mathrm{tha}^{-1}$. The sowing was done directly on the pot, leaving two plants per pot after thinning. They have been irrigated with poor quality water with a concentration of $0.2 \mathrm{mg} \mathrm{L}^{-1} \mathrm{Cd}$. Plants of radish, corn and beet were harvested at 30,60 and 90 days, respectively, separated in shoot and roots and placed in air circulation oven. The data were submitted to analysis of variance. The present study led to demonstrate that application of bentonite in soil irrigated with poor quality water had a significant positive effect on development of radish, corn and beet crops, ie, influenced at $1 \%$ probability the dry biomass of roots of radish, corn and beet and the dry biomass of shoot of the corn. Generally the bentonite promoted the retention of cadmium in the soil, evidenced by the reduction of the concentration and/or accumulation of this metal in the shoot and roots of radish, corn and beet. Bentonite favored the reduction of bioaccumulation and translocation factors of cadmium thereby increasing the concentration of this element in soil in relation to the plants and in shoot in relation to root, except of corn.
\end{abstract}

Keywords: Bioaccumulation, Translocation, Heavy metals, Clay.

Abbreviations: Cd_cadmium; TI_translocation index; $\mathrm{TF}_{-}$translocation factor; $\mathrm{BFP}$ _ bioaccumulation factor of cadmium in plant; $\mathrm{BFR} \_$bioaccumulation factor of cadmium in root; $\mathrm{KCl} \_$potassium chloride; $\mathrm{P}_{2} \mathrm{O}_{5}$ super phosphate.

\section{Introduction}

The supply of drinking water is decreasing while demand for water is increasing, so researchers are currently looking for ways to recycle water through the reuse of urban wastewater for irrigation and other purposes (Dantas et al., 2014). In general, wastewater comprises liquid wastes generated by households, industry, commercial sources, as a result of daily usage, production and consumption activities. The wastewater is also a resource that can be applied for productive uses since wastewater contains nutrients that have the potential for use in agriculture, aquaculture and other activities. It is a rich source of nutrients and provides all the moisture necessary for crop growth. However in the composition of wastewater have chemical pollutants, i.e., heavy metals, which, by irrigation may be transported to soils and may affect soil flora and fauna causing crop contamination and consequently, the food chain (Cunha Filho et al., 2014). Some of these heavy metals may bioaccumulate in the soil while others, e.g., $\mathrm{Cd}$ and $\mathrm{Cu}$, may be redistributed by soil fauna such as earthworms (Kruse and Barrett, 1985; Maxted et al., 2007). Cadmium (Cd) is a heavy metal naturally present in soil; it is non-essential and highly toxic to most organisms, having toxicity 2 to 20 times higher than many other heavy metals (Vassilev et al., 1998). Plants can extract $\mathrm{Cd}$ from the soil and transport it via the xylem into shoots and leaves where easily it accumulates thus can be readily absorbed into the human body throughout the food chain (Zheng et al., 2010). An excessive level of cadmium ions in the water can affect the bio-systems and be a threat to human beings. Hence the removal of cadmium ions from the water and wastewater is highly important. Essential to the reduction of the pollution pressure on arable and other farmland, in situ immobilization technologies have gained prominence and rapid implementation, being generally costeffective and non-disruptive (Lee et al., 2013). A number of these technologies have been developed by adding various natural or synthetic materials, such as clay minerals (Sun et al., 2013) which inactivate mobile $\mathrm{Cd}$ and reduce its labile pool and ecotoxicity. Numerous studies have confirmed that number adsorbents such as clay minerals, for example, bentonite, can effectively immobilize $\mathrm{Cd}$ in soils and improve soil properties as $\mathrm{pH}$, fertility, water storage capacity, etc. Adsorption is a traditional method to immobilize $\mathrm{Cd}$ from aqueous environment; it is quite popular due to its simplicity and high efficiency. The bentonite is a rock containing clay minerals, predominantly smectite group and quartz impurities. In some varieties are also kaolinite and illite. Due 
to the large area of surface specific, high cation exchange capacity and low cost, bentonite has a broad application prospect in agriculture and it is probably one of the most promising materials that interact with many heavy metals in contaminated soils and waters. According to Sdiri et al. (2011), this clay can be effectively used for the treatment of contaminated wastewater. This material is found in large quantities in the municipality of Boa Vista, Paraiba State, Brazil.

Knowing, however, that each clay mineral presents greater or lesser adsorption capacity, its efficiency in removing metallic cations of soil / wastewater systems should be assessed in relation to each of these cations, separately. Like cadmium, a heavy metal regarded as an element of high toxicity, not biodegradable, they can be easily accumulated in living tissue and readily absorbed into the human body throughout the food chain. Therefore, the objective of this study was to evaluate the effect of bentonite clay on cadmium adsorption contained in the lower quality water, with the plants test radish, corn and sugar beet.

\section{Results and Discussion}

\section{Shoot and root dry of the plants}

The reduction in plant growth and, consequently, dry biomass is one of the common symptoms of heavy metal stress on plants with special reference to $\mathrm{Cd}$ (Hadi et al., 2014). According to several authors, this may be attributed to the inhibition of chlorophyll synthesis decreasing photosynthetic activity (Chauhan and Joshi, 2010; Nagajyoti et al., 2010).

The present study indicated differences in above-ground shoot and below-ground root dry weight of radish, corn and beet. These results may be attributed to bentonite doses applied in the cultivated soil and irrigated with low quality water containing cadmium. That is, the biomass, generally, increased as a function of increasing amounts of bentonite applied to the soil (Table 1) because, probably by adsorption process. The bentonite in the soil, adsorbing metals, such as cadmium, decreases the deleterious effect of this metal on plants.

According to the analysis of variance the application of increasing doses of bentonite significantly influenced at $1 \%$ probability the dry biomass of roots of radish, corn and beet and the dry biomass of shoot of the corn (Table 2).

Dry weight of root radish increased by around $31.38 \%$ as a function of treatments ranging from $1,119 \mathrm{~g} /$ pot $\left(0 \mathrm{t} \mathrm{ha}^{-1}\right.$ bentonite) to $1,469 \mathrm{~g} /$ pot $\left(90 \mathrm{t} \mathrm{ha}^{-1}\right.$ bentonite) (Figure $2 \mathrm{~A}$ ). The application of bentonite in soil resulted in an increase of dry biomass of shoot and root of corn around 12.21 and $13.93 \%$, respectively (Figure $2 \mathrm{~B}$ and $2 \mathrm{C}$ ). The increase in dry biomass of roots of beet was greater than occurred with radish, i.e., it was approximately $53.5 \%$, ranging from 9.10 to $13.97 \mathrm{~g} /$ pot according to equation Figure 2D. Increases in dry biomass of shoots and/or roots of radish, corn and beet, indicate that bentonite, probably by adsorption mechanism, reduced the cadmium content available in the soil thus promoting the development of these cultures. As KabataPendias and Pendias (2000), the presence of high concentrations of $\mathrm{Cd}$ in the root environment can influence the absorption and metabolism of other nutrients showing stunting due to deficiency of these nutrients such as phosphorous, which has been shown to form insoluble complexes with Cd (Foy et al., 1978) affecting plant growth. For example, Augusto et al. (2014) studied the effect of cadmium used in the development of mustard, observed that
$10 \mathrm{mg} \mathrm{L}^{-1}$ of $\mathrm{Cd}$ in the solution caused a $40 \%$ decrease in biomass.

\section{Cadmium concentration in shoot and root}

The $\mathrm{Cd}$ concentrations in shoots of radish and $\mathrm{Cd}$ concentrations in the roots of radish and beet crops were significantly influenced by increasing doses of bentonite (Table 3).

The Cd concentrations in shoots and roots radish ranged from 0.64 to $0.47 \mathrm{mg} \mathrm{kg}^{-1}$ and 0.33 to $0.21 \mathrm{mg} \mathrm{kg}^{-1}$ promoting a reduction in the order of 26.59 and $35.78 \%$, respectively, when comparing the control with the higher dose (Figure 3A and 3B). It is observed in Table 1 that the $\mathrm{Cd}$ concentrations in shoots radish grown in soil without bentonite, and at doses 30 and $60 \mathrm{t} \mathrm{ha}^{-1}$ were above or equal to the maximum tolerable value for human consumption of vegetables, roots and tubers and other fresh food which is 0.5 $\mathrm{mg} \mathrm{kg}{ }^{-1}$ cadmium according to ABIA (1985).

The incorporation of bentonite in the soil influenced the $\mathrm{Cd}$ concentration in the root of the beet, reducing by $27.27 \%$ in relation to the increasing doses of bentonite (Figure 3C). It is verified that the beet (root) cultivated in the soil without the bentonite had the $\mathrm{Cd}$ concentration $0.73 \mathrm{mg} \mathrm{kg}^{-1}$, above the maximum value allowed for vegetables, roots and tubers, that is, unfit for consumption, whereas, beet in the soil with doses of bentonite 30, 60 and $90 \mathrm{tha}^{-1}$ had the concentration of $\mathrm{Cd}$ $0,44,0,49$ and $0,53 \mathrm{mg} \mathrm{kg}^{-1}$, respectively, below or equal to the maximum value allowed, which proves the beneficial effect of the bentonite. It is important to emphasize that this culture was irrigated with water containing cadmium in the maximum concentration allowed to discharge effluents, and even at this limit, it is worrisome the consumption of food irrigated with water of inferior quality, with the presence of this metal because this represents great risk to human health (Kumar et al., 2012; Marin et al., 2010).

Comparing the concentration of $\mathrm{Cd}$ in the parts of the plant, it was observed that the highest concentrations of this element occurred in the roots of the corn in relation to the aerial part, corroborating with Wang et al. (2014).

The application of increasing doses of bentonite to the soil generally decreased the concentrations and/or accumulations of cadmium in both the roots and the aerial part of the plants. Perhaps the main reason for this is related to the increase of the specific surface of the soil, increasing the electric charges in the colloids and consequently the cationic exchange capacity. Thus, the adsorption of cadmium in the soil increased, reducing the concentration of the element in the available soil solution to be absorbed by the plants. This positive effect may reflect the increase in plant biomass.

\section{Cadmium accumulated in shoot and root}

Increasing doses of bentonite significantly influenced the cumulative amount of $\mathrm{Cd}$ in shoot and root of radish and root of corn (Table 4). Except for the cumulative amount of $\mathrm{Cd}$ in corn, the best fit was provided by linear regression model (Figure 4). According to Tito et al. (2016), bentonite did not significantly influence the cumulative amount do $\mathrm{Cu}$ in the radish, however, was significative about this element in the corn.

The Cd accumulated in shoot and root radish (Figures 4A and 4C) had a reduction of about 39.38 and $20.0 \%$, ranging from 0.0016 to $0.0010 \mathrm{mg} /$ pot and 0.00038 to $0.00032 \mathrm{mg} /$ pot, respectively. This reduction, through the incorporation of bentonite, has been beneficial, since excessive accumulation 
Table 1. Dry biomass, cadmium concentration $\left(\mathrm{mg} \mathrm{kg}^{-1}\right)$ and accumulated ( $\left.\mathrm{g} / \mathrm{pot}\right)$, the translocation index (TI,\%), translocation factor (TF), bioaccumulation factor of cadmium in plant (BFP) and root (BFR) of radish, corn and beet plant as a function of increasing doses of bentonite.

\begin{tabular}{|c|c|c|c|c|c|c|c|c|c|c|}
\hline \multirow[t]{2}{*}{ Bentonite $\mathrm{t} \mathrm{ha}^{-1}$} & \multicolumn{2}{|c|}{$\begin{array}{l}\text { Dry biomass } \\
\mathrm{g}\end{array}$} & \multicolumn{2}{|c|}{$\begin{array}{l}\text { Concentration } \\
\mathrm{mg} \mathrm{kg}^{-1}\end{array}$} & \multicolumn{2}{|c|}{$\begin{array}{l}\text { Accumulated } \\
\mathrm{mg} / \text { pot }\end{array}$} & \multirow{2}{*}{$\begin{array}{r}\text { TI } \\
\%\end{array}$} & \multirow[t]{2}{*}{$\mathrm{TF}$} & \multirow[t]{2}{*}{ BFP } & \multirow[t]{2}{*}{ BFR } \\
\hline & Shoot & Root & Shoot & Root & Shoot & Root & & & & \\
\hline & Radish & & & & & & & & & \\
\hline 0 & 2.17 & 1.18 & 0.61 & 0.31 & 0.0017 & 0.00038 & 81.55 & 1.95 & 3.52 & 1.05 \\
\hline 30 & 2.16 & 1.21 & 0.65 & 0.32 & 0.0014 & 0.00039 & 77.77 & 2.03 & 3.29 & 1.08 \\
\hline 60 & 2.31 & 1.67 & 0.50 & 0.24 & 0.0011 & 0.00036 & 75.57 & 2.09 & 2.51 & 0.81 \\
\hline 90 & $\begin{array}{l}2.29 \\
\text { Corn }\end{array}$ & 1.41 & 0.47 & 0.21 & 0.0010 & 0.00029 & 76.68 & 2.24 & 2.20 & 0.71 \\
\hline 0 & 81.6 & 13.7 & 0.054 & 0.25 & 0.0044 & 0.0034 & 55.68 & 0.21 & 0.47 & 0.85 \\
\hline 30 & 82.9 & 12.8 & 0.058 & 0.19 & 0.0048 & 0.0025 & 65.68 & 0.32 & 0.38 & 0.66 \\
\hline 60 & 81.0 & 14.7 & 0.060 & 0.21 & 0.0049 & 0.0031 & 61.47 & 0.31 & 0.41 & 0.70 \\
\hline 90 & $\begin{array}{l}93.5 \\
\text { Beet }\end{array}$ & 15.1 & 0.042 & 0.26 & 0.0039 & 0.0039 & 48.95 & 0.16 & 0.46 & 0.88 \\
\hline 0 & 9.10 & 8.5 & 1.17 & 0.74 & 0.0110 & 0.0063 & 61.80 & 1.55 & 2.23 & 2.51 \\
\hline 30 & 7.35 & 11.1 & 1.08 & 0.51 & 0.0079 & 0.0056 & 56.35 & 2.12 & 1.86 & 1.73 \\
\hline 60 & 7.63 & 13.3 & 1.08 & 0.53 & 0.0083 & 0.0071 & 53.84 & 2.06 & 1.88 & 1.80 \\
\hline 90 & 8.28 & 13.2 & 0.91 & 0.52 & 0.0077 & 0.0069 & 51.13 & 1.75 & 1.67 & 1.76 \\
\hline
\end{tabular}

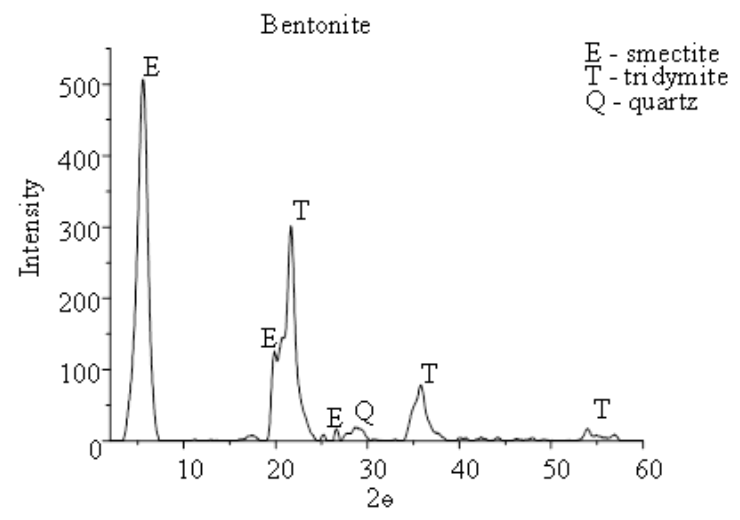

Fig 1. Diffractogram of bentonite obtained by X-ray Diffraction.

Table 2. Summary of the analyses of variance for the dry biomass of the shoot and root of the radish, corn and beets, irrigated with poor quality of water with increasing doses of bentonite.

\begin{tabular}{|c|c|c|c|c|c|c|c|}
\hline \multirow{3}{*}{ Source of Variation } & \multirow{3}{*}{ DF } & \multicolumn{6}{|c|}{ Mean Square } \\
\hline & & Radish & & Corn & & Beets & \\
\hline & & shoot & root & shoot & root & shoot & root \\
\hline Bentonite & 3 & $0.025 \mathrm{~ns}$ & $0.205 * *$ & $137.81 * *$ & $4.317 * *$ & $2.43 \mathrm{~ns}$ & $20.10^{* *}$ \\
\hline Linear & 1 & - & $0.266 * *$ & $226.63 * *$ & $7.515 * *$ & - & $52.60 * *$ \\
\hline Quadratic & 1 & - & $0.084 *$ & $124.93 *$ & $1.756^{*}$ & - & $6.9 \mathrm{~ns}$ \\
\hline Error & 12 & 0.168 & 0.021 & 14.60 & 0.252 & 1.10 & 2.21 \\
\hline $\mathrm{VC}(\%)$ & & 18.34 & 10.66 & 4.51 & 3.56 & 12.97 & 12.91 \\
\hline Mean (g) & & 2.24 & 1.36 & 84.79 & 14.10 & 8.09 & 11.53 \\
\hline
\end{tabular}

Table 3. Summary of the analyses of variance for the cadmium concentration in the shoot and root of the radish, corn and beets irrigated with poor quality of water with increasing doses of bentonite.

\begin{tabular}{|c|c|c|c|c|c|c|c|}
\hline \multirow{3}{*}{$\begin{array}{l}\text { Source of } \\
\text { Variation }\end{array}$} & \multirow{3}{*}{ DF } & \multicolumn{6}{|c|}{ Mean Square } \\
\hline & & \multicolumn{2}{|c|}{ Radish } & \multicolumn{2}{|l|}{ Corn } & \multicolumn{2}{|l|}{ Beets } \\
\hline & & shoot & root & shoot & $\operatorname{root}^{1}$ & shoot $^{2}$ & root \\
\hline Bentonite & 3 & $0.029 *$ & $0.0114 * *$ & $0.0002 \mathrm{~ns}$ & $0.005 \mathrm{~ns}$ & $0.019 \mathrm{~ns}$ & $0.048 *$ \\
\hline Linear & 1 & $0.064 *$ & $0.028 * *$ & - & - & - & $0.081 *$ \\
\hline Quadratic & 1 & $0.004 \mathrm{~ns}$ & $0.001 \mathrm{~ns}$ & - & - & - & $0.048 *$ \\
\hline Error & 12 & 0.008 & 0.0007 & 0.0001 & 0.002 & 0.036 & 0.01 \\
\hline $\mathrm{VC}(\%)$ & & 16.99 & 10.03 & 18.94 & 10.46 & 19.69 & 17.79 \\
\hline Mean $\left(\mathrm{mg} \mathrm{kg}^{-1}\right)$ & & 0.56 & 0.27 & 0.05 & 0.48 & 0.98 & 0.58 \\
\hline
\end{tabular}

$\mathrm{DF}=$ Degree of Freedom, ${ }^{\mathrm{ns}},{ }^{*}$ and ${ }^{* *}$ no significant, significant to the 5 and $1 \%$ level, respectively.VC $=$ Variation Coefficient. ${ }^{1.2}$ Data transformed in $V_{\mathrm{x}}$ and $1 / \mathrm{x}$, respectively. 

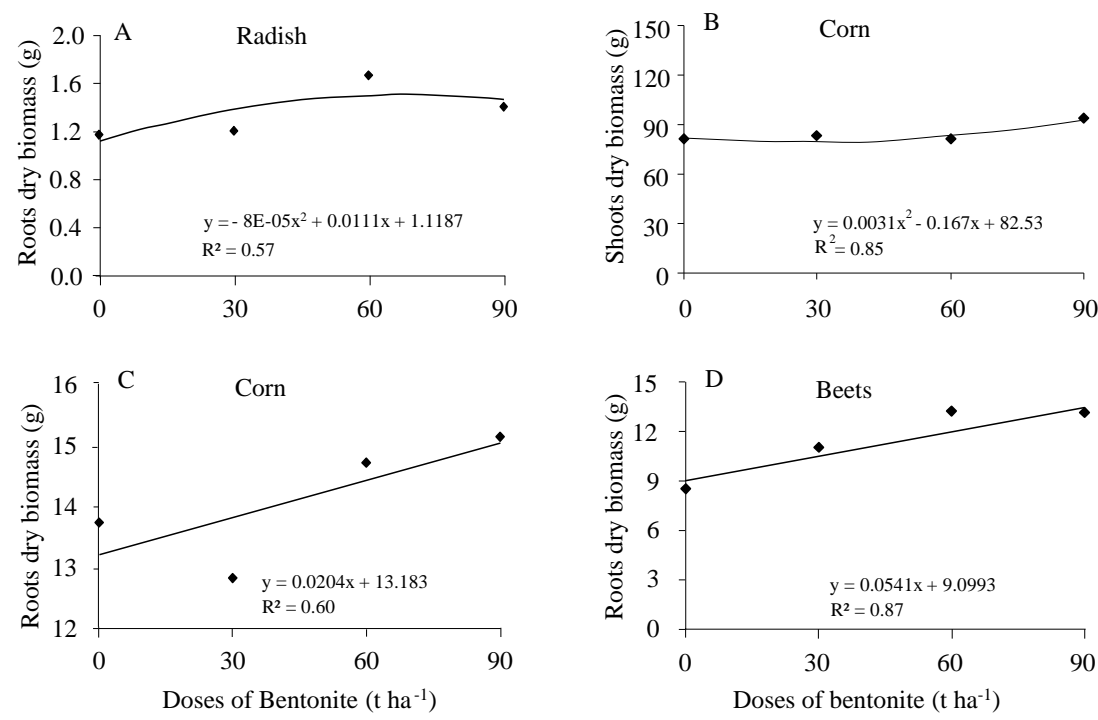

Fig 2. Dry biomass of the radish (A), corn (C) and beet (D) roots, and dry biomass of shoot corn (B) irrigated with lower quality water due to increasing doses of bentonite.
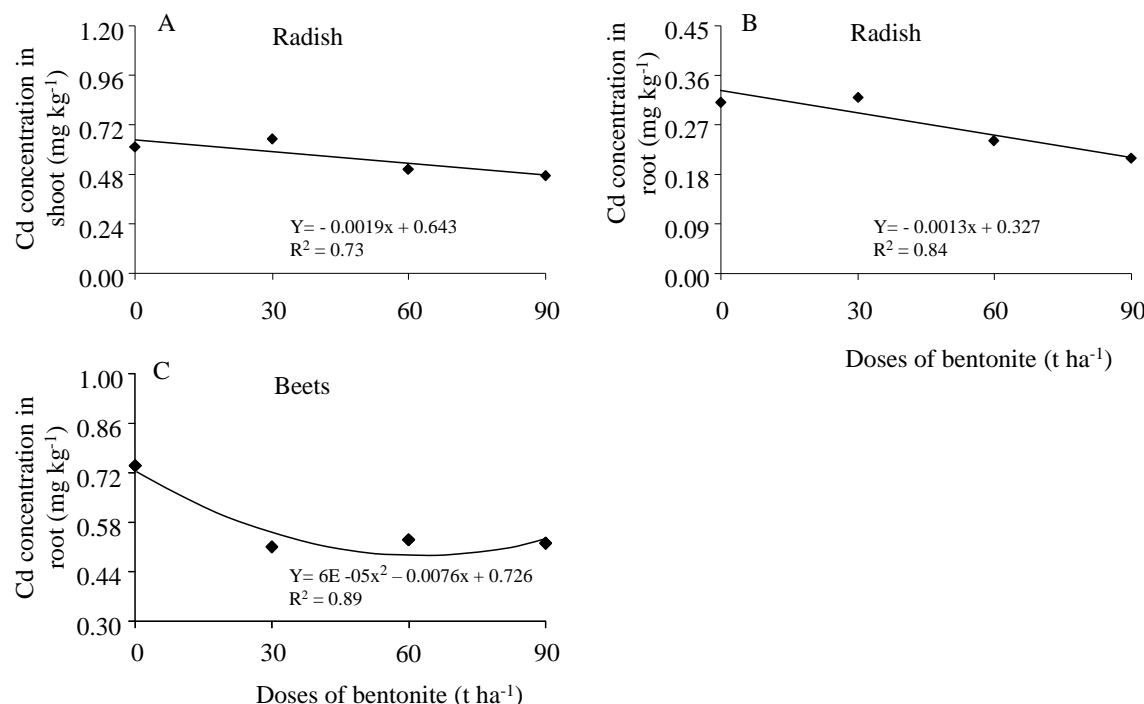

Doses of bentonite $\left(\mathrm{tha}^{-1}\right)$

Fig 3. Cadmium concentration in the shoots of radishes (A) and Cd concentration in the root of radish (B) and beet (C), depending on dose increasing bentonite.

Table 4. Summary of the analyses of variance for the accumulated cadmium in the shoot and root of the radish, corn and beets irrigated with poor quality of water with increasing doses of bentonite.

\begin{tabular}{|c|c|c|c|c|c|c|c|}
\hline \multirow{3}{*}{$\begin{array}{l}\text { Source of } \\
\text { Variation }\end{array}$} & \multirow{3}{*}{ DF } & \multicolumn{6}{|c|}{ Mean Square } \\
\hline & & \multicolumn{2}{|l|}{ Radish } & \multicolumn{2}{|l|}{ Corn } & \multicolumn{2}{|l|}{ Beets } \\
\hline & & shoot & $\operatorname{root}^{1}$ & shoot & $\operatorname{Root}^{1}$ & Shoot $^{2}$ & root \\
\hline Bentonite & 3 & $3.35 \mathrm{e}^{-7} *$ & $7.17 \mathrm{e}^{-9} *$ & $7.17 \mathrm{e}^{-7} \mathrm{~ns}$ & $0.00013^{*}$ & $382.07 \mathrm{~ns}$ & $6 \mathrm{e}^{-6} \mathrm{~ns}$ \\
\hline Linear & 1 & $0.000001^{* *}$ & $0.00000 * *$ & - & $0.00003 \mathrm{~ns}$ & - & - \\
\hline Quadratic & 1 & $0.000 \mathrm{~ns}$ & $0.000 \mathrm{~ns}$ & - & $0.0003 *$ & - & - \\
\hline Error & 12 & $6.08 \mathrm{e}^{-8}$ & $1.57 \mathrm{e}^{-9}$ & $8.3 \mathrm{e}^{-7}$ & 0.00003 & 979.33 & 0.000006 \\
\hline $\mathrm{VC}(\%)$ & & 18.81 & 11.13 & 20.19 & 11.04 & 25.34 & 26.67 \\
\hline Mean (mg) & & 0.0013 & 0.0003 & 0.0045 & 0.056 & 123.50 & 0.009 \\
\hline
\end{tabular}

$\mathrm{DF}=$ Degree of Freedom, ${ }^{\mathrm{ns}}, *$ and ${ }^{* *}$ no significant, significant to the 5 and $1 \%$ level, respectively.VC $=$ Variation Coefficient. ${ }^{1,2}$ Data transformed in $\sqrt{\mathrm{x}}$ and $1 / \mathrm{x}$, respectively 

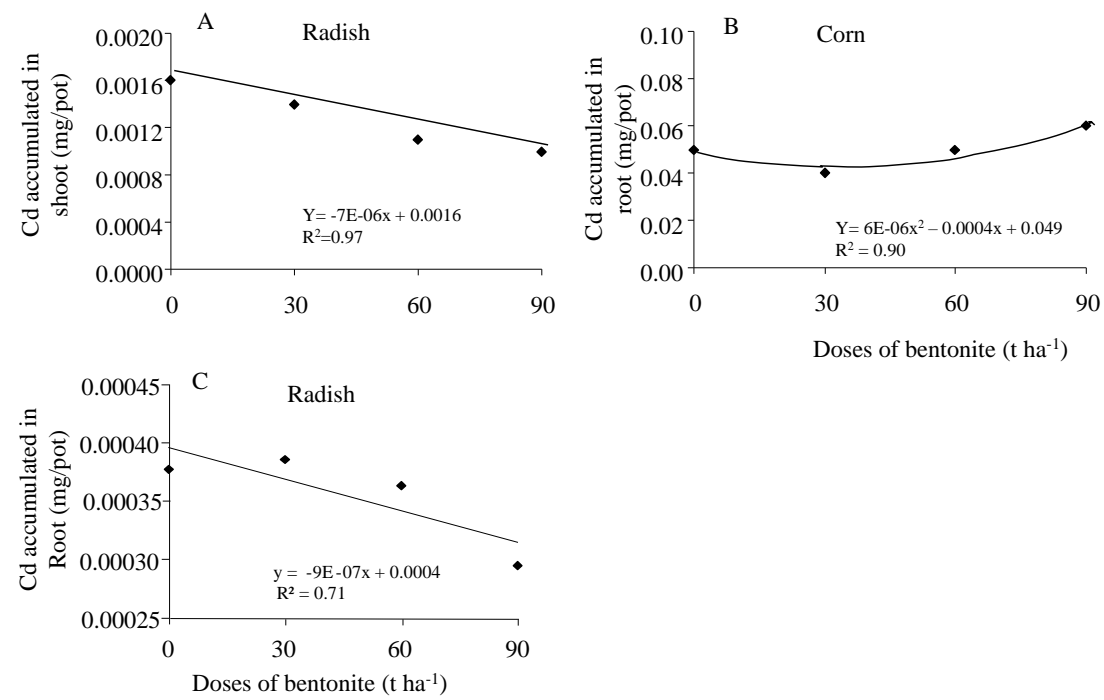

Fig 4. Amount of $\mathrm{Cd}$ accumulated in shoots of radishes (A) and amount $\mathrm{Cd}$ accumulated in the root of radish (C) and corn (B), depending on dose increasing bentonite.

Table 5. Summary of the analyses of variance for the cadmium translocation index (TI), translocation factor (TF), bioaccumulation factor of cadmium in plant (BFP) and bioaccumulation factor of cadmium in root (BFR) of the radish, corn and beets irrigated with poor quality of water with increasing doses of bentonite.

\begin{tabular}{|c|c|c|c|c|}
\hline \multirow{2}{*}{$\begin{array}{l}\text { Source } \\
\text { Variation }\end{array}$} & \multirow[t]{2}{*}{ DF } & \multicolumn{3}{|c|}{ Mean Square } \\
\hline & & Radish & Corn & Beets \\
\hline & \multicolumn{4}{|c|}{ translocation index } \\
\hline Bentonite & 3 & $27.04 \mathrm{~ns}$ & $214.93 *$ & $82.65 \mathrm{~ns}$ \\
\hline Linear & 1 & - & $83.09 \mathrm{~ns}$ & - \\
\hline Quadratic & 1 & - & $531.88 * *$ & - \\
\hline $\mathrm{VC}(\%)$ & & 4.37 & 11.58 & 12.87 \\
\hline \multirow[t]{2}{*}{ Mean } & & 77.89 & 58.56 & 55.78 \\
\hline & \multicolumn{4}{|c|}{ translocation factor } \\
\hline Bentonite & 3 & $0.061 \mathrm{~ns}$ & $0.024 \mathrm{~ns}$ & $0.286^{*}$ \\
\hline Linear & 1 & - & - & $0.064 \mathrm{~ns}$ \\
\hline Quadratic & 1 & - & - & $0.765^{* *}$ \\
\hline $\mathrm{VC}(\%)$ & & 12.38 & 33.09 & 13.37 \\
\hline \multirow[t]{2}{*}{ Mean } & & 2.08 & 0.25 & 1.87 \\
\hline & \multicolumn{4}{|c|}{ bioaccumulation factor of cadmium in plant } \\
\hline Bentonite & 3 & $1.57 * *$ & $0.007 \mathrm{~ns}$ & $0.218 \mathrm{~ns}$ \\
\hline Linear & 1 & $4.50 * *$ & - & - \\
\hline $\mathrm{VC}(\%)$ & & 7.97 & 16.72 & 19.93 \\
\hline \multirow[t]{2}{*}{ Mean } & & 2.88 & 0.43 & 1.91 \\
\hline & \multicolumn{4}{|c|}{ bioaccumulation factor of cadmium in root } \\
\hline Bentonite & 3 & $0.132 * *$ & $0.049 \mathrm{~ns}$ & $0.559 *$ \\
\hline Linear & 1 & $0.333 * *$ & - & $0.94 *$ \\
\hline $\mathrm{VC}(\%)$ & & 10.03 & 20.12 & 17.79 \\
\hline Mean & & 0.91 & 0.77 & 1.95 \\
\hline
\end{tabular}
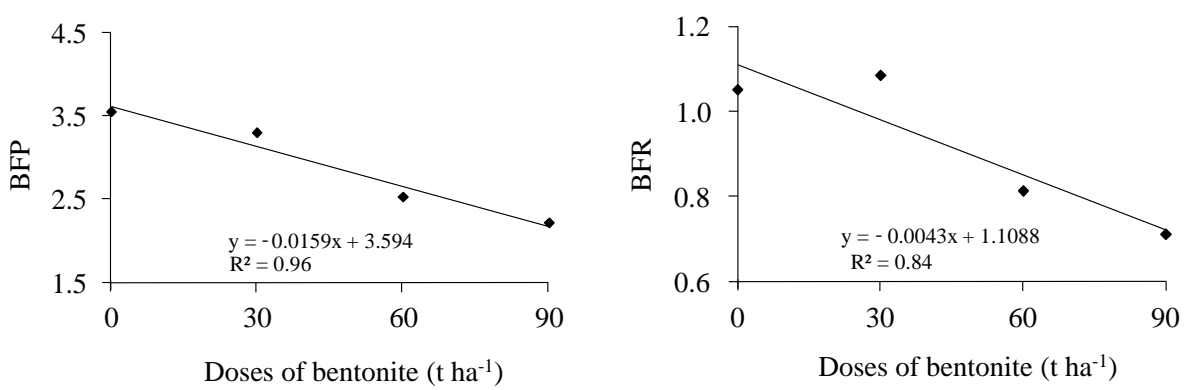

Fig 5. Bioaccumulation factor of cadmium in plant (BFP) and in root (BFR) of radish depending on dose increasing bentonite. 


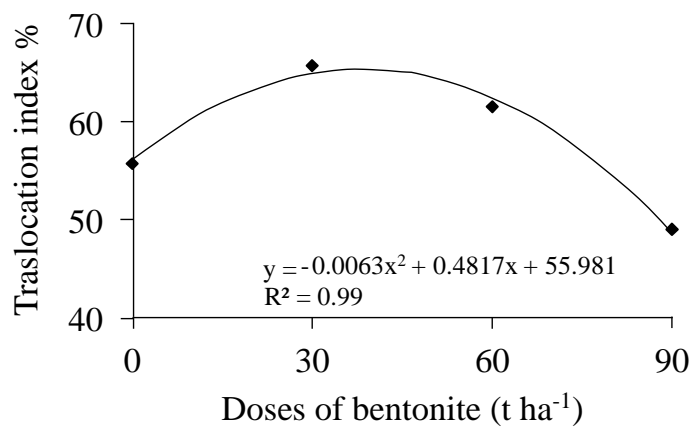

Fig 6. Cadmium translocation index in corn plants according to the increasing doses of bentonite.

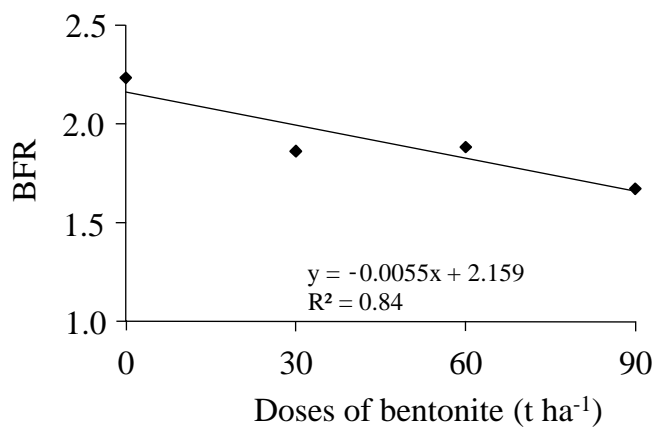

Fig 7. Bioaccumulation factor of cadmium in root (BFR) of beet depending on dose increasing bentonite.

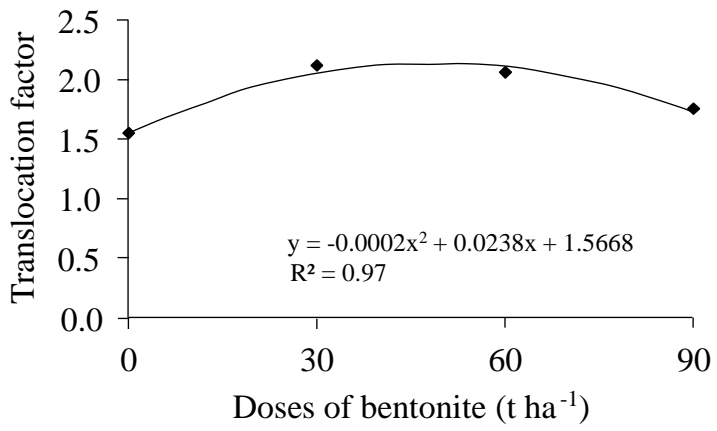

Fig 8. Cadmium translocation factor in beet plants according to the increasing doses of bentonite.

of heavy metals in agricultural soils, such as cadmium, through wastewater irrigation can result in contamination of the soil, and increased absorption of metals heavy by cultures, affecting food quality and safety (Muchuweti et al., 2006).

Only the bentonite dose corresponding to $30 \mathrm{t} \mathrm{ha}^{-1}$ promoted the reduction of $14.29 \%$ in the Cd accumulation in the corn root while the other doses did not favor the reduction of the $\mathrm{Cd}$ accumulation in the root (Figure $4 \mathrm{~B}$ ) occurring an increase of $26.53 \%$ when compared to the control with the highest dose. Probably due to the value of the dry biomass of the root being higher in the doses of 60 and $90 \mathrm{t} \mathrm{ha}^{-1}$ of bentonite (Figure 2C). According to Table 4, there was highest accumulation of $\mathrm{Cd}$ the corn roots than in the aerial part, corroborating Yu et al. (2016), who observed a greater accumulation of this element of the rice roots. On the contrary, it was observed in the radish and beet, where the highest accumulation of $\mathrm{Cd}$ was in the aerial part of the plants.

The irrigation of crops with lower quality water can accumulate heavy metals in soil and/or increase absorption of these metals by plants causing major health risks to consumers (Khan et al., 2008). As discussed in the previous item, the incorporation of bentonite clay in soil was beneficial since it reduced the accumulation of $\mathrm{Cd}$ in plants due to loss of soil Cd transfer to plants. This is probably because the adsorption effect of bentonite.

Cadmium translocation index, translocation factor, bioaccumulation factor of cadmium in plant and in root

The ability of a plant to accumulate metals from soils can be estimated using the bioaccumulation potential in plant (BFP) and/or in root (BFR), while its ability to translocate them from the roots to the shoots is measured using the translocation factor (TF). These factors can be used to estimate a plant's potential for phytoremediation purposes.

The values of BFP and BFR of radish decreased significantly as a function of increasing doses of bentonite (Table 5), indicating an increase in the adsorption of cadmium in the soil, decreasing the concentration in the plant parts. This behavior is beneficial since clay minerals such as 
bentonite have a great potential to adsorb pollutants due to their large specific surface area, the layered structure, and high cation exchange capacity (Bhattacharyya and Gupta, 2008). However, the BFP and BFR (control and dose $30 \mathrm{t} \mathrm{ha}^{-}$ $\left.{ }^{1}\right)$ for cadmium had values more than unity (Table 1), indicating high bioaccumulation potential of radish for this metal. The BFP and BFR of radish ranged from 3.59 to 2.16 and from 1.11 to 0.72 showing a reduction of $39.82 \%$ and $34.90 \%$, respectively, presenting better fit in linear model (Figure 5).

Although the bentonite did not influence the TI and TF of radish (Table 5), the values of this last factor $>1$ indicated a very efficient ability to transport cadmium from roots to shoots, most likely due to efficient metal transport systems according to Tito et al. (2016). These authors observed that increasing doses of bentonite promoted copper retention in the soil reducing the translocation of the element to the aerial part of several cultures. It worth noting that radish is a suitable plant for phytoextraction for this metal. This can be confirmed by the concentration data and the amounts of cadmium (Table 1) which were higher in the aerial part than in the roots. This is important because the comestible part of plant is the root. According corn data presented in Table 1, the BFP, BFR and TF values were smaller than unity, indicating low bioaccumulation potential of plant for this metal which is suitable element for phytostabilization. Although there was no significant effect of the increasing doses of bentonite on BFP, BFR and TF factors (Table 5), it can be seen in Table 1 that the application of these doses, mainly 30 and $60 \mathrm{t} \mathrm{ha}^{-1}$, had a tendency to increase the levels of cadmium to the soil in relation to the plant and / or root, thus reducing the values of BFP and BFR. This, probably, because the presence of bentonite causes higher adsorption of cadmium in the soil. According to the values of TI and TF, there was a tendency to increase the cadmium concentration of the aerial part in relation to bentonite doses, however, the large difference between root and shoot concentrations indicates an important restriction of the internal transport of $\mathrm{Cd}$ from roots towards shoot, resulting in higher root concentrations rather than translocation to leaves (Table 1). Bentonite applied to the soil had a significant effect on the level of 5\% probability in the TI for corn (Table 5), showing a quadratic effect (Figure 6) ranging according to equation from $55.98 \%$ to $48.30 \%$, ie, a reduction in the order of $13.64 \%$ when compared to control with the higher dose.

As in the radish, the BFR values of beet decreased significantly at $5 \%$ of probability as a function of the bentonite doses (Table 5), ranged from 2.159 to 1.664 showing a reduction of $22.93 \%$ (Figure 7). However, all the BFR values were above the unit, showing the potential of bioaccumulation in roots, or $\mathrm{Cd}$ phytoextraction capacity. The BFP values also decreased in relation to control (without bentonite), however no significantly with bentonite doses (Table 5).The TF value above the unit indicates the predominance of cadmium in the aerial part in relation to the roots as can be confirmed with the concentrations of this element in roots and shoot (Table 1). The variation of these values (from 1.567 to 2.089) according to the doses of bentonite was significantly at $5 \%$ of probability increasing $33.32 \%$ according to Table 5 . The behavior of these values is shown in Figure 8.

\section{Materials and Methods}

\section{Plant materials}

The cultures used in this experiment were beets (Beta vulgaris), radish (Raphanus sativus) and corn (Zea mays L.).

\section{Soil, bentonite and experimental site}

This study was carried out greenhouse conditions, from July 2015 to October 2015 at the Agricultural Engineering Department, Federal University of Campina Grande, Paraiba, Brazil.

The experiments were conducted with on a loamy sand soil classified as a Eutrophic Red Latosol (Embrapa, 2006), collected in Campina Grande region at a 0-20 cm soil depth. After collecting the soil, samples were air-dried, crushed, sieved through a $2 \mathrm{~mm}$ sieve and analyzed using the procedures recommended by Embrapa (1997).

The bentonite clay used in this study was collected from a Paraiba State region. The samples were air dried and sieved with $2 \mathrm{~mm}$ and $0.074 \mathrm{~mm}$ mesh in order to proceed chemical and X-ray diffraction analyzes, respectively.

\section{Composition of soil and bentonite}

The following attributes of soil samples were as follows: $\mathrm{pH}$ $\left(\mathrm{H}_{2} \mathrm{O}\right)=6.0$; electrical conductivity $=0.16 \mathrm{mmhos} \mathrm{cm}^{-1} ; \mathrm{Ca}=$ $2.10 \mathrm{cmol}_{\mathrm{c}} \mathrm{kg}^{-1} ; \mathrm{Mg}=2.57 \mathrm{cmol}_{\mathrm{c}} \mathrm{kg}^{-1} ; \mathrm{Na}=0.06 \mathrm{cmol}_{\mathrm{c}} \mathrm{kg}^{-1}$; $\mathrm{K}=0.14 \mathrm{cmol}_{\mathrm{c}} \mathrm{kg}^{-1} ; \mathrm{H}+\mathrm{Al}=1.78 \mathrm{cmol}_{\mathrm{c}} \mathrm{kg}^{-1}$; organic carbon $=5.5 \mathrm{~g} \mathrm{~kg}^{-1} ; \mathrm{P}=45.0 \mathrm{mg} \mathrm{kg}^{-1}$ and $\mathrm{Cd}=0.015 \mathrm{mg} \mathrm{kg}^{-1}$.

The X-rays diaphactogram of this bentonite is presented in Figure 1. The diaphactogram picks observed are typical of the smectite (E) clays, and picks of tridymite $(T)$, a silicate mineral and polymorph of high temperature of quartz. Picks of quartz $(\mathrm{Q})$ are observed although in a low quantity.

\section{Treatments and doses}

The experiment for each plant consisted of four doses of bentonite: $0.0 ; 10.7 ; 21.4$ and $32.1 \mathrm{~g} \mathrm{~kg}^{-1}$, corresponding to 0 . 30. 60 and $90 \mathrm{t} \mathrm{ha}^{-1}$, respectively, with 4 repetitions in a completely randomized design totaling 16 experimental units (plastic pots).

\section{Incubation condition and time after treatments}

Soil samples mixed with the bentonite dose corresponding to treatment were placed in plastic pots with $5 \mathrm{~kg}$ capacity for beets and radish; and for corn in plastic pots with $14 \mathrm{~kg}$. These mixtures were incubated for 20 days with moisture corresponding to field capacity.

\section{Conduct of the study}

According to Novais et al. (1991), the radish and beet was fertilized with $1.11 \mathrm{~g}$ of urea, $1.25 \mathrm{~g}$ of potassium chloride $(\mathrm{KCl})$ and $8.3 \mathrm{~g}$ of super phosphate $\left(\mathrm{P}_{2} \mathrm{O}_{5}\right)$; corn was fertilized with $3.11 \mathrm{~g}$ of urea, $3.5 \mathrm{~g}$ of $\mathrm{KCl}$ and $23.33 \mathrm{~g}$ of $\mathrm{P}_{2} \mathrm{O}_{5}$.

After the incubation period and NPK fertilization, the seeds of each crop were sown and 8 days after the emergency of seedlings, a thinning was conducted leaving two plants per 
pot. From this period was initiated irrigation of crops with lower quality water, ie, with water having cadmium (Cd) 0.2 $\mathrm{mg} \mathrm{\textrm {L } ^ { - 1 }}$. This concentration corresponds to the maximum permissible for effluents, by CONAMA Resolution $n^{\circ} .20$ of June 18, 1996. At the end of each culture cycle, according to the amount of water used in irrigation, the cumulative concentration in soil for cultivation of radish, corn and beet was 0.28 ; 0.64 and $0.84 \mathrm{mg} \mathrm{kg}-1$ of $\mathrm{Cd}$, respectively.

\section{Harvesting of plant material}

At 30; 60 and 90 days of experimental period the plants radish, corn and beet, respectively, were harvested and separated into aerial part and roots, washed with distillated water, and placed in paper bags in order to be dried in forced air stove at $65^{\circ} \mathrm{C}$ during $48 \mathrm{~h}$. After drying, the plants were triturated and samples were weighed for foliar analyses.

\section{Determination of cadmium in shoot and root of the plants and calculated the factors used}

Plant samples were submitted to cadmium determination conducted after nitric-perchloric digestion, according to Embrapa procedures (Embrapa, 1997), using an Inductively Coupled Plasma Optical Emission Spectroscopy (ICP OES), as described by Oliva et al. (2003). The cumulative amount of Cd in dry biomass of the aerial part (shoot) and roots (mg / pot) was calculated by the expression $\mathrm{Cd}$ accumulated shoot or Cdaccumulated root $=\{$ Dry Biomass of shoot or Dry Biomass of root $(\mathrm{g}) \mathrm{x}$ element concentration $\left.\left(\mathrm{mg} \mathrm{kg}^{-1}\right)\right\} /$ 1000. The translocation index (TI) was determined by using the follow expression (Abichequer and Bohnen, 1998): (Cdaccumulated shoot/ Cdaccumulated in the complete plant) $\mathrm{x}$ 100. The translocation factor (TF) gives the leaf/root cadmium concentration and depicts the ability of the plant to translocate the metal species from roots to leaves (shoot) at different concentrations. This index was calculated by the relationship: $\mathrm{TF}=$ (cadmium concentration in the aerial part of the plant $\left(\mathrm{mg} \mathrm{kg}^{-1}\right)$ (shoot)/ cadmium concentration in the root $\left(\mathrm{mg} \mathrm{kg}^{-1}\right)$ ) (Gupta et al., 2008). The bioaccumulation factor (BF), an index of the ability of the plant to accumulate a particular metal with respect to its concentration in the soil substrate (Ghosh and Singh, 2005), was calculated as follows: $\mathrm{BFP}=$ cadmium concentration in the complete plant $\left(\mathrm{mg} \mathrm{kg}^{-1}\right) /$ cadmium concentration in the soil $\left(\mathrm{mg} \mathrm{kg}^{-1}\right)$, or, to calculate metal bioaccumulation only in the root was: $\mathrm{BFR}=$ cadmium concentration in the plant root $\left(\mathrm{mg} \mathrm{kg}^{-1}\right) /$ cadmium concentration in the soil $\left(\mathrm{mg} \mathrm{kg}^{-1}\right)$.

\section{Statistical analysis}

SISVAR statistical program (Ferreira, 2011) was employed to analyze the obtained results, by using the $\mathrm{F}$ test and regression polynomials, which were used to adjust the data when significant.

\section{Conclusion}

The present study led to demonstrate that application of bentonite in soil irrigated with poor quality water had a significant positive effect on development of radish, corn and beet crops. Generally the bentonite promoted the retention of cadmium in the soil, evidenced by the reduction of the concentration and/or accumulation of this metal in the shoot and roots of radish, corn and beet. Bentonite favored the reduction of bioaccumulation and translocation factors of cadmium thereby increasing the concentration of this element in soil in relation to the plants and in shoot in relation to root, except of corn

\section{Acknowledgement}

Special thanks to the Coordination for the Superior Level Personal Improvement (CAPES) for the scholarship granted to the first author.

\section{References}

Associação Brasileira das Indústrias da Alimentação - ABIA (1985) Compêndio da legislação dos alimentos. São Paulo.

Abichequer AD, Bohnen H (1998) Eficiência de absorção, translocação e utilização de fósforo por variedades de trigo. Rev Bras Ci Solo. 22(1): 21-26.

Augusto AS, Bertoli AC, Cannata MG, Carvalho R, Bastos ARR (2014) Avaliação dos efeitos tóxicos de $\mathrm{Cd}$ e $\mathrm{Pb}$ na cultura da mostarda (Brassica juncea). Eng Sanit Ambient Edição Especial.: 61-68.

Bhattacharyya KG, Gupta SS (2008) Adsorption of a few heavy metals on natural and modified kaolinite and montmorillonite: a review. Adv Colloid Inter Sci. 140:114131

Chauhan A, Joshi PC (2010) Effect of ambient air pollutants on wheat and mustard crops growing in the vicinity of urban and industrial areas. New York Sci J. 3 (2): 52-60.

Cunha Filho FF, Neto AM, Nascimento CWA, Biondi CM, Neto JAS (2014) Metais pesados em amostras de água de irrigação da maior região produtora de hortaliças folhosas de Pernambuco. Sci Plena. 10:1-7.

Dantas ILA, Faccioli GG, Mendonça LC, Nunes TP, Viegas PRA and Santana LOG (2014) Viabilidade do uso de água residuária tratada na irrigação da cultura do rabanete (Raphanus sativus L.). Rev Amb Água. 9(1):109-117.

EMBRAPA, Centro Nacional de Pesquisa de Solos (1997) Manual de métodos de analise de solo, 2rd. Embrapa, Rio de Janeiro.

EMBRAPA, Centro Nacional de Pesquisa de Solos (2006) Sistema brasileiro de classificação de solos, 2 rd. Embrapa Solos, Rio de Janeiro.

Ferreira DF (2011) Sisvar: a computer statistical analysis system. Ci Agr. 35(6):1039-1042.

Foy CD, Chaney RL, White MC (1978) The physiology of metal toxicity in plants. Ann Rev Plant Physiol. 29:511566.

Ghosh M, Singh SP (2005) A comparative study of cadmium phytoextraction by accumulator and weed species. Environ Pollut. 133: 365-371.

Gupta S, Nayek S, Saha RN, Satpati S (2008) Assessment of heavy metal accumulation in macrophyte, agricultural soil and crop plants adjacent to discharge zone of sponge iron factory. Environ Geol. 55:731-739.

Hadi F, Hussain F, Hussain M, Sanaullah Ahmad A, Ur Rahman S, Ali N (2014) Phytoextraction of Pb and Cd; the effect of Urea and EDTA on Cannabis sativa growth under metals stress. Int J Agron Agri Res. 5 (3): 30-39.

Kabata-Pendias A, Pendias H (2000) Trace Elements in Soils and Plants, Third Edition. 3rd., ilustrada, revisada. Editora CRC Press.

Khan S, Cao Q, Zheng YM, Huang YZ, Zhu YG (2008) Health risks of heavy metals in contaminated soils and food crops irrigated with wastewater in Beijing, China. Envir Poll. 152:686-692.

Kruse EA, Barrett GW (1985) Effects of municipal sludge and fertilizer on heavy metal concentration in earthworms. Environ Poll 38:235-244. 
Kumar PS, Ramalingam S, Sathyaaselvabala V, Kirupha SD, Murugesan A, Sivanesan S (2012) Removal of Cd(II) from aqueous solution by agricultural waste cashew nut shell. Korean J Chem Engin. 29:756-768.

Lee SS, Lim JE, El-Azeem SAMA, Choi B, Oh SE, Moon DH, Ok YS (2013) Heavy metal immobilization in soil near abandoned mines using eggshell waste and rapeseed residue. Environ Sci Pollut Res 20:1719-1726

Marin ABP, Aguilar MI, Ortuno JF, Meseguer VF, Saez J, Florenz M (2010) Biosorption of $\mathrm{Zn}$ (II) by orange waste in batch and packed bed systems. J Chem Tech Biotech. 85: $1310-1318$

Maxted AP, Black CR, West HM, Crout NMJ , McGrath SP, Young SD (2007) Phytoextraction of cadmium and zinc from arable soils amended with sewage sludge using Thlaspi caerulescens: Development of a predictive model. Environ Pollut. 150: 363-372.

Muchuweti M, Birkett JW, Chinyanga E, Zvauya R, Scrimshaw MD, Lester JN (2006) Heavy metal content of vegetables irrigated with mixture of wastewater and sewage sludge in Zimbabwe: implications for human health. Agric Ecos Environ. 112: 41-48.

Nagajyoti PC, Lee KD, Sreekanth TVM (2010) Heavy metals, occurrence and toxicity for plants: a review. Environ Chem Lett. 8:199-216.

Novais RF, Neves JCL, Barros NF (1991) Ensaio em ambiente controlado. In: Oiveira AJ (ed.) Métodos de pesquisa em fertilidade do solo. Embrapa-SEA, Brasília.

Oliva SR, Raitio H, Mingorance MD (2003) Comparison of two wet digestion procedures for multi-element analysis of plant samples. Com Soil Sci Plant Anal. 34:2913-2923.
Sdiri A, Higashi T, Hatta T, Jamoussi F, Tase N (2011) Evaluating the adsorptive capacity of montmorillonitic and calcareous clays on the removal of several heavy metals in aqueous systems. Chem Eng J. 172(1): 37-46.

Sun YB, Sun GH, Xu YM, Wang L, Liang XF, Lin DS (2013) Assessment of sepiolite for immobilization of cadmium-contaminated soils. Geoderma. 193-194:149155.

Tito GA, Chaves LHG, Vasconcelos ACF, Fernandes JD (2016) Bentonite effect on copper adsorption on plants irrigated with low quality water. Int $\mathrm{J}$ Current Res. 8: 41598-41604.

Yu H, Liu C, Zhu J, Li F, Deng DM, Wang Q, Liu C (2016) Cadmium availability in rice paddy fields from a mining area: The effects of soil properties highlighting iron fractions and $\mathrm{pH}$ value. Environ Pollut. 209: 38-45.

Vassilev A, Tsonev T, Yordanov I (1998) Physiological response of barley plants (Hordeum vulgare) to cadmium contamination in soil during ontogenesis. Environ Pollut. 103:287-293.

Wang F, Ouyang W, Hao F, Lin C, Song N (2014) In situ remediation of cadmium-polluted soil reusing four byproducts individually and in combination. J Soils Sedim. 14: 451-461.

Zheng L, Dang Z, Zhu C, Yi X, Zhang H, Liu C (2010) Removal of cadmium(II) from aqueous solution by corn stalk graft copolymers. Bioresour Technol. 101: 58205826 . 